\title{
PEMBENTUKAN DAN PELATIHAN DUTA ANTI ROKOK PADA KOMUNITAS SAKA BAKTI HUSADA DI SMK KESEHATAN $X$ KOTA TASIKMALAYA TAHUN 2019
}

\author{
OLEH
}

Sinta Fitriani,SKM,MKM, Mitha Mutiara Nurdin, Hesti Adzani Ramadhanti, Ai Wulandari, Iqbal Subekti, Nurhasanah,Intania Fildatan Yusup

\section{STIKes Respati \\ taniesa1571@gmail.com}

\section{A. DASAR PEMIKIRAN}

Rokok merupakan benda yang sudah tidak asing di telinga kita. Tentu saja, hampir bisa dipastikan setiap orang mengetahui tentang apa itu rokok. Dari masyarakat bawah, atas, anak kecil maupun orang dewasa jelas mengenal apa itu rokok. Benda berbahan dasar tembakau kering yang dilinting pada selembar kertas. Bagi kaum adam, rokok seperti identitas sebagai pria. Dimana ketika mereka menghisap rokok dan menghebuskan asapnya mereka merasa seperti pria yang sesungguhnya. Menurut sebagian dari mereka merasa jika seorang pria tidak merokok maka pria itu bukanlah pria yang sesungguhnya.

Hal semacam ini sungguh sangat miris mengingat banyak resiko yang bisa diterima seorang perokok namun para perokok itu malah memilih untuk mempertahankan gengsi mereka ketimbang memikirkan resiko-resiko yang mungkin diterimanya di hari depan nanti. Sangat ironis memang, bahwa manusia tidak memperhatikan keseimbangan alam akibat proses pembakaran rokok ke paru-paru mereka. Kebiasaan merokok telah menjadi budaya di berbagai bangsa di belahan dunia. Latar belakang merokok beraneka ragam, dikalangan remaja dan pria dewasa adalah faktor gengsi dan agar disebut jagoan. Sedangkan kalangan orang tua adalah stres, karena ketagihan adalah faktor penyebab keinginan merokok.

Rokok telah menjadi faktor risiko utama pada 6 dari 8 penyebab kematian di dunia yang mengancam miliyaran pria, wanita dan anak-anak dalam abad ini. Sekitar $80 \%$ kematian terkait rokok terjadi di negara- negara sedang berkembang. Di Indonesia, merokok meningkatkan resiko kematian 1,3-8,2 kali diantara penderita penyakit kronik. Merokok juga dapat menimbulkan dampak negatif bagi orang yang berbeda di sekelilingnya. Resiko yang ditanggung perokok pasif lebih berbahaya dari pada perokok aktif karena daya tahan terhadap zat-zat yang berbahaya sangat rendah (WHO, 2008). Dengan jumlah perokok di Indonesia saat ini mencapai $57 \%$ penduduk atau kurang lebih 100 juta orang, artinya kini Indonesia menduduki peringkat ketiga dalam urutan negara yang jumlah perokoknya paling banyak. Jumlah 
perokok di seluruh dunia saat ini mencapai 1,1 miliar orang.

Sekolah Menengah Kejuruan X yang berada di kota Tasikmalaya. Hasil dari survey pendahuluan yang dilakukan didapatkan data sebagai berikut : sebagian besar siswa diperoleh informasi pubertas dan permasalahan remaja dari teman sebayanya yaitu $87,3 \%$,

Permasalahan remaja yang diperoleh adalah siswa laki-laki sebagian besar merokok (73,2\%). Dan 90\% siswa telah memilik pacar serta rata-rata telah melakukan aktifitas praseksual seperti pegangan tangan pelukan serta ciuman. Berdasarkan hasil wawancara dengan kepala sekolah menyatakan bahwa di sekolah tidak ada kegiatan PIKR (Pusat Informasi dan Konseling Remaja) yang dibina oleh pihak puskesmas. Dari hasil survey tersebut penulis memfokuskan meyelesaikan masalah merokok pada remaja laki-laki. Karena permasalahan remaja laki-laki yang merokok sangat besar. Untuk itu penulis membuat sebuah program untuk mengurangi dan memberantas yang merokok di SMK X. program ini bertujuan untuk menciptakan generasi muda bebas rokok dengan cara membuat Komunitas Remaja Anti Rokok.

\section{B. TUJUAN KEGIATAN}

Terlaksana kegiatan pembentukan dan pembinaan duta anti rokok SMK Kesehatan X Kota Tasikmalaya Tahun 2019

\section{BENTUK KEGIATAN}

Kegiatan ini meliputi

1) Sosialisasi kegiatan

2) Pemilihan duta anti rokok

3) Pelatihan duta anti rokok

\section{SASARAN}

Sasaran kegiatan ini yaitu siswa Saka Bhakti Husada (SBH) yang berada di SMK DPI terdiri dari 14 orang putri dan 2 orang putra.

\section{E. WAKTU DAN TEMPAT PELAKSANAAN}

Tempat kegiatan dilaksanakan di SMK DPI pada hari Jumat tanggal 08 November 2019 pukul 15.00 sd 17.00 dengan rincian kegiatan sebagai berikut:

\begin{tabular}{|l|l|}
\hline \multicolumn{1}{|c|}{ Kegiatan } & \multicolumn{1}{c|}{$\begin{array}{c}\text { Waktu } \\
\text { Pelaksanaan }\end{array}$} \\
\hline $\begin{array}{l}\text { Sosialisasi dan } \\
\text { pemilihan }\end{array}$ & 04 Oktober 2019 \\
\hline $\begin{array}{l}\text { Pembuatan Materi } \\
\text { dan Media } \\
\text { Demonstrasi }\end{array}$ & 7-11 Oktober 2019 \\
\hline Pre-Test & 08 November 2019 \\
\hline Pemberian Materi & 08 November 2019 \\
\hline $\begin{array}{l}\text { Demonstrasi } \\
\text { Bahaya Rokok }\end{array}$ & 08 November 2019 \\
\hline $\begin{array}{l}\text { Pelatihan } \\
\text { Komunitas }\end{array}$ & 08 November 2019 \\
\hline Post-Test & 08 November 2019 \\
\hline $\begin{array}{l}\text { Pembentukan } \\
\text { Komunitas }\end{array}$ & 08 November 2019 \\
\hline $\begin{array}{l}\text { Pembuatan Pesan } \\
\text { Kesehatan }\end{array}$ & 08-09 November \\
\hline $\begin{array}{l}\text { Pembuatan } \\
\text { Sertifikat }\end{array}$ & 12 November 2019 \\
\hline $\begin{array}{l}\text { Penyerahan } \\
\text { Sertifikat }\end{array}$ & 15 November 2019 \\
\hline
\end{tabular}




\section{F. HASIL KEGIATAN DAN PEMBAHASAN}

Hasil kegiatan yang telah dilaksanakan adalah sebagai berikut

\section{1) Sosialisasi kegiatan}

Sosialisasi kegiatan

pembentukan duta antirokok diawali dengan kegiatan survei pengetahuan dan perilaku merokok pada siswa SMK DPI kemudian hasil survey tersebut dipaparkan pada saat kegiatan musyawarah sekolah yang turut dihadiri oleh pimpinan sekolah, guru dan karyawan lainnya.

Hasil kesepakatan bersama, dibentuk duta anti rokok yang diambil dari organisasi saka bakti husada yang terdiri dari 25 orang siswa.

\section{2) Pemilihan duta anti rokok}

Pemilihan duta anti rokok dilakukan atas kriteria yang telah ditetapkan seperti siswa dengan kemampuan komunikasi yang aktif dan tidak berperilaku merokok.

Berdasarkan kriteria diatas dihasilkan 16 orang siswa yang tergabung dalam organisasi saka bakti huada yang terdiri 14 orang siswi dan 2 orang siswa.

Penetapan kriteria tersebut memiliki dasar, misal kemampuan komunikasi diersyaratkan karena kemampuan komunikasi menjadi dasar dalam pelaksanaaan kegiatan penyuluhan.

Sedangkan untuk catatan duta yang terpilih memiliki rekam jejak tidak pernah berperilaku meroko. Hal ini dikarenakan Duta anti rokok perlu menjadi role model sehingga bisa menjadi contoh sasaran untuk berperilaku sehat dengan tidak merokok.

3) Pelatihan duta anti rokok

Pelatihan duta anti rokok dilaksanakan satu hari setelah penetapan duta, dilaksanakan di sekolah SMK Kesehatan DPI dengan materi tentang bahaya merokok pada remaja

Dalam proses pelatihan tidak hanya perubahan pengetahuan siswa yang diintervensi, akan tetapi dengan melatih kemampuan komunikasi sehingga duta memiliki kemampuan dalam melaksanakan penyuluhan sesuai target.

Berdasarkan hasil pre test dan post test dapat disimpulkan bahwa perubahan score pre test dan post test mengalami peningkatan yaitu nilai rata rata pre test adalah 6,5 dan mengalami peningkatan perubahan score pengetahuan post test rata rata nilai adalah 8.

Sedangkan kemampuan komunikasi sasaran mengalami peningkatan dimana, sasaran mengalami peningkatan kemampuan berkomunikasi secara langsung dengan penilaian dilakukan dengan metode memperagakan kegiatan penyuluhan yang dibuat secara berkelompok dengan materi yangdisampaikan adalah pemberian informasi tentang bahaya rokok dan ajakan untuk melakukan aktifitas yang dapat mencegah perilaku merokok.

Hal ini sesuai dengan teori bahwa pelatihan adalah suatu proses dimana orang-orang mencapai kemampuan tertentu, untuk membantu mencapai tujuan organisasi. 
Pelatihan merupakan proses
pembelajaran lebih
menekankan pada praktek daripada
teori yang dilakukan seseorang atau
kelompok dengan menggunakan
pelatihan orang dewasa dan
bertujuan
$\begin{aligned} & \text { kemampuan dalam satu atau } \\ & \text { beberapa } \\ & \text { tertentu. jenis keterampilan }\end{aligned}$

Pelatihan masyarakat di bidang kesehatan adalah pelatihan yang diberikan kepada masyarakat terkait keterampilan tertentu yang dapat dilakukan oleh masyarakat di bidang kesehatan. Tujuan dari pelatihan kesehatan adalah mengubah perilaku individu, masyarakat dibidang kesehatan. Tujuan ini menjadikan kesehatan sebagai suatu yang bernilai di masyarakat, menolong 39 individu agar mampu secara mandiri atau kelompok mengadakan kegiatan untuk mencapai hidup sehat (Kemenkes RI:2014)

Pemberdayaan
dimaknai sebagai suatu proses
menuju berdaya atau proses
pemberian daya atau kekuatan atau
kemampuan, dan atau proses
pemberian daya atau kekuatan atau
kemampuan dari pihak yang
mempunyai daya kepada pihak yang
tidak atau kurang berdaya.(Teguh,
2004)

G. KESIMPULAN DAN SARAN

Kesimpulan dari kegiatan ini adalah terbentuk dan terbinanya duta anti rokok pada komunitas Saka Bakti Husada di SMK Kesehatan Dura Pratama Indonesia
Penulis menyarankan untuk pihak sekolah bisa bekerjasama dengan petugas kesehatan ssetempat untuk kegiatan pembinaan komuntas anak sekolah dibidang kesehatan

\section{H. DAFTAR PUSTAKA}

Herniyatun, 2009, Efektivitas Edukasi Peer Group Terhadap Perubahan Pengetahuan, Sikap dan Ketrampilan dalam pencegahaan Kanker Serviks Di Kabupaten Kebumen, Jurnal Ilmiah Kesehatan Keperawatan, Vol. 5, No. 2, Tahun 2009, hlm. 92-100.

Karisma, Lia S, 2011, Pengaruh Promosi Kesehatan Terhadap Pengetahuan Tentang Kanker Serviks dan Partisipasi Wanita dalam Deteksi Dini Kanker Serviks, Tesis, Universitas Sebelas Maret.

Herniyatun, 2009, Efektivitas Edukasi Peer Group Terhadap Perubahan Pengetahuan, Sikap dan Ketrampilan dalam pencegahaan Kanker Serviks Di Kabupaten Kebumen, Jurnal Ilmiah Kesehatan Keperawatan, Vol. 5, No. 2, Tahun 2009, hlm. 92-100.

Kementrian Kesehatan Republik Indonesia, Jakarta.

Kementrian Kesehatan Republik Indonesia, 2014, Standar Penyelenggaraan Pelatihan Tenaga Kesehatan dan Masyarakat Di Bidang Kesehatan, Pengembangan Badan Pemberdayaan SDM 
Kesehatan Pusat Pendidikan dan Pelatihan Tenaga

Kesehatan, Jakarta.

Nottoatmodjo, 2010, Promosi

Kesehatan Teori dan

Aplikasi, Rineka Cipta, Jakarta.

S.J, Soemarto, 2003, Inovasi Partisipasi danGood

Governance, Yayasan Obor
Indonesia, diakses tanggal 8 Agustus 2015 ,

(Turindraatp.blogspot.com/20 15/08/Pengertian

Partisipasi.html). Sudijono, A, 2006, Pengantar Evaluasi Pendidikan, Rajawali Press, Jakarta.

\section{DOKUMENTASI}
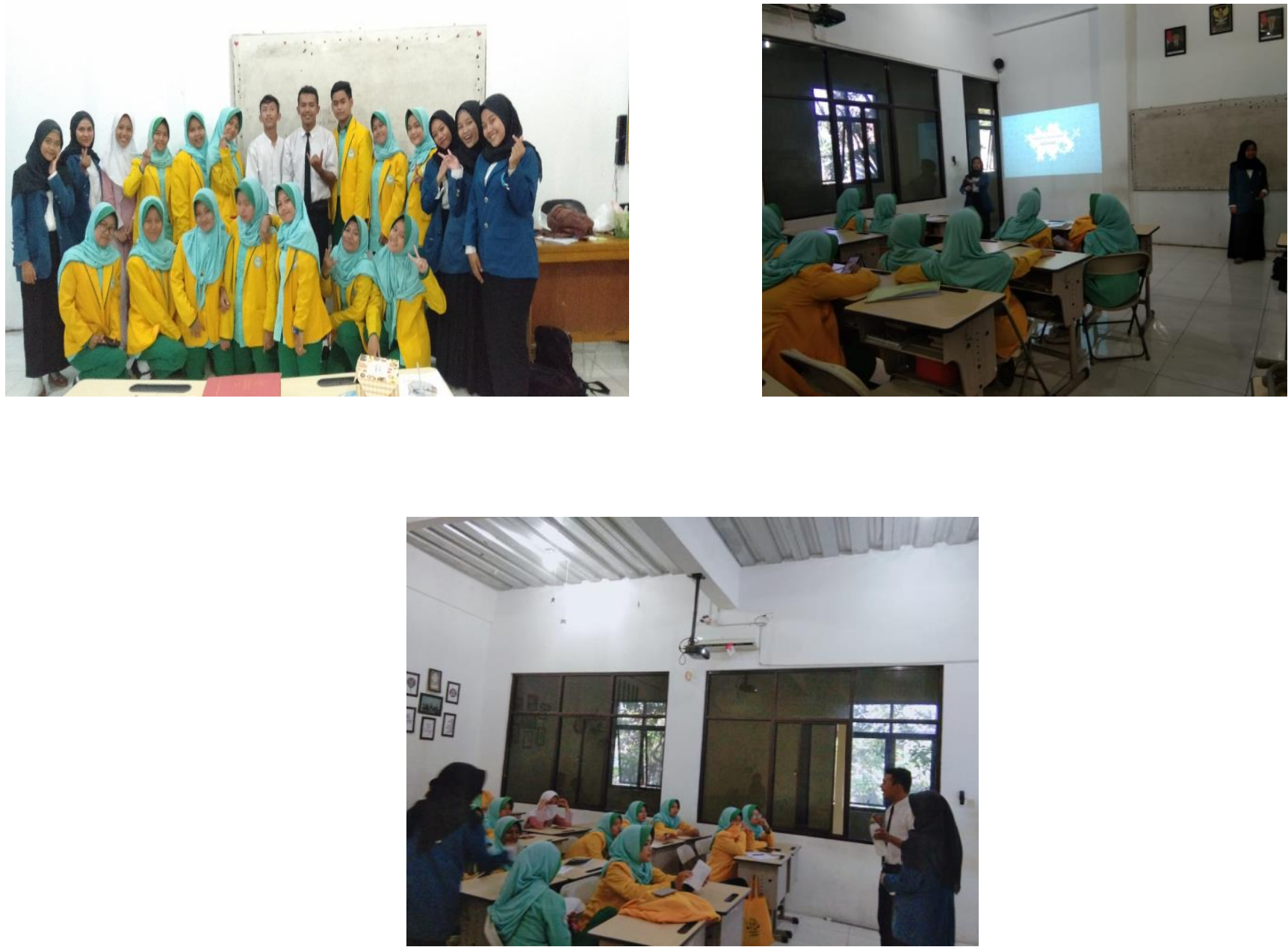